\title{
PENN STATE STUDIES in ROMANCE LITERATURES
}

\section{Editors Frederick A. de Armas Norris J. Lacy Allan Stoekl}

Refiguring the Hero:

From Peasant to Noble in

Lope de Vega and Calderón

by Dian Fox

Don Juan and the Point of Honor:

Seduction, Patriarchal Society,

and Literary Tradition

by James Mandrell

Narratives of Desire:

Nineteenth-Century Spanish

Fiction by Women

by Lou Charnon-Deutsch

Garcilaso de la Vega and the

Italian Renaissance

by Daniel L. Heiple

Allegories of Kingship:

Calderón and the

Anti-Machiavellian Tradition

by Stephen Rupp

Acts of Fiction:

Resistance and Resolution

from Sade to Baudelaire

by Scott Carpenter

Grotesque Purgatory:

A Study of Cervantes's Don Quixote, Part II by Henry W. Sullivan

Spanish Comedies and Historical

Contexts in the 1620 s by William R. Blue

The Cultural Politics of Tel Quel:

Literature and the Left in the

Wake of Engagement

by Danielle Marx-Scouras

Madrid 1900:

The Capital as Cradle of

Literature and Culture

by Michael Ugarte

Ideologies of History in the Spanish Golden Age by Anthony J. Cascardi
Medieval Spanish Epic:

Mythic Roots and Ritual Language

by Thomas Montgomery

Unfinished Revolutions:

Legacies of Upheaval in

Modern French Culture

edited by Robert T. Denommé and

Roland H. Simon

Stages of Desire:

The Mythological Tradition in Classical and Contemporary Spanish Theater by Michael Kidd

Fictions of the Feminine in the Nineteenth-Century Spanish Press by Lou Charnon-Deutsch

The Novels and Plays of Eduardo Manet:

An Adventure in Multiculturalism by Phyllis Zatlin

Fernando de Rojas and the Renaissance Vision: Phantasm, Melancholy, and Didacticism in Celestina by Ricardo Castells

The Poetics of Empire in the Indies:

Prophecy and Imitation in

La Araucana and Os Lusíadas by James Nicolopulos

María de Zayas Tells Baroque Tales of Love and the Cruelty of Men by Margaret Greer

Vision, the Gaze, and the Function of the Senses in Celestina by James F. Burke

Adventures in Paradox:

Don Quixote and the Western Tradition by Charles D. Presberg 
$+$

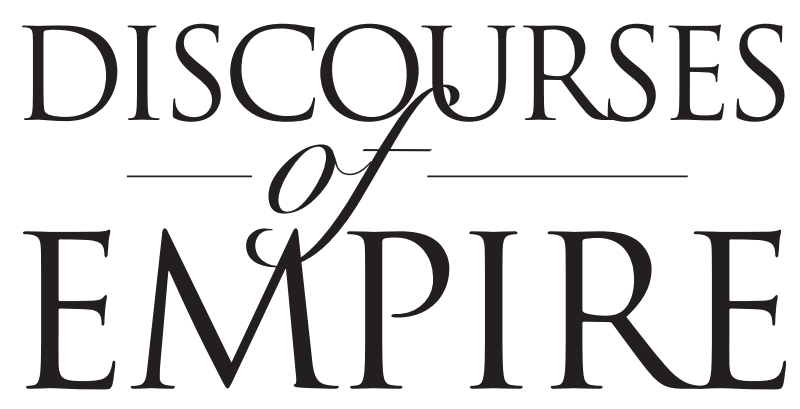

Gounter-Spic Siterature in Barly Nodern Spain

$$
+
$$

B A R B A R A S M E R K A

The Pennsyloania State University Press

University Lark, Pennsyluania 
Publication of this book has been aided by a grant from the Program for Cultural Cooperation Between Spain's Ministry of Education and Culture and United States Universities.

Library of Congress Cataloging-in-Publication Data

Simerka, Barbara, 1957-

Discourses of empire : counter-epic literature in early modern Spain / Barbara Simerka.

p. $\quad$ cm. - (Penn State studies in Romance literatures)

Includes bibliographical references and index.

ISBN 0-271-02282-5 (cloth : alk. paper)

1. Historical drama, Spanish-History and criticism.

2. Spanish drama-Classical period, 1500-1700-History and criticism.

3. Imperialism in literature.

I. Title. II. Series.

PQ6121.H5 S56 2003

862'.051409358—dc21

2003004688

Copyright $\left({ }_{2} 2003\right.$ The Pennsylvania State University

All rights reserved

Printed in the United States of America

Published by The Pennsylvania State University Press,

University Park, PA 16802-1003

It is the policy of The Pennsylvania State University Press to use acid-free paper. Publications on uncoated stock satisfy the minimum requirements of American National Standard for Information Sciences-Permanence of Paper for Printed Library Materials, ANSI Z39.48-1992. 